\title{
THE IMPACT OF FLOODING ON THE OPERATIONAL RELIABILITY OF REAL ESTATE IN THE KURSK REGION
}

\author{
Vladimir Khaustov ${ }^{1 *}$, Lorina Kruglova ${ }^{2}$, Natalia Bredikhina ${ }^{1}$, Teimur Guseinov ${ }^{1}$ \\ ${ }^{1}$ Southwest State University, Kursk, Russia \\ ${ }^{2}$ Sochi State University, Sochi, Russia
}

The example of industrial and residential areas shows the negative impact of the processes of underflooding of territories, on the operational reliability of real estate objects. The causes of the manifestation and development of these complex processes are revealed. To overcome the anthropogenic impact on groundwater, technological recommendations have been proposed, economic and social nature.

Key words: Groundwater, Soils, Industrial and residential buildings, Underflooding of territories, Foundation, Resource depletion, Pollution.

\section{INTRODUCTION}

Among the engineering-geological processes that accompany urbanization and complicating conditions of construction and operation of buildings and various engineering structures, seismicity, karst, suffusion and the presence of specific properties of the soil, the presence of tectonic faults, gullying, quicksand, subsidence in the loess soils, underflooding areas are allocated. The latter is the most common (especially within industrial and residential agglomerations) and large-scale social and environmental-economic damage associated with it. The process of underflooding associated with the rise of the groundwater, can be caused by both natural and manmade factors.

In the KMA region, natural underflooding processes are associated with a large amount of precipitation. (up to $550 \div 650 \mathrm{~mm} /$ year) of a clear or storm character and the presence in the terrain of terrain free depressions contributing to the infiltration of precipitation into groundwater, as well as with floods of rivers in the flood.

More diverse causes of underflooding are caused by human activity and the main significant one - is the creation of ponds and reservoirs.

\section{RESEARCH METHODS}

In the Kursk region there are more than 700 artificial reservoirs, the largest of them is the cooling pond of the Kursk nuclear power station (hereinafter referred to as KNPS) [1]. The facilities of the nuclear power station are located on the left bank of the Seim river on the floodplain, the first and second terraces above the floodplain. At their basis overlie rocks chalk marl-Upper Cretaceous strata, overlain by sand and sandy-argillaceous alluvial and diluvial eluvial- quaternary sediments capacity 13,3 to $18,4 \mathrm{~m}$. By varying grain size sand river terraces quaternary aquifer confined to a minor depth occurrence from the surface : $0,1 \div 6 \mathrm{~m}$ on the floodplain and the first terrace above the floodplain and up to $14 \div 16 \mathrm{~m}$ on the second terrace from the surface. The discharge of groundwater occurred in the river Seim with a slope of ground flow - 0,003 $\div 0,007$ north-north - west. Before the construction of the KNPS the mode corresponded to a seasonal change in the amount of precipitation and temperature.

In the process of building of the nuclear power station there occurred the noticeable changes in the relief and hydrogeological conditions. The huge volumes of rocks are displaced, the river Seim is displaced, the reservoir is created (the cooling pond) with an area of $22 \mathrm{~km} 2$, the water mirror of which is $10 \mathrm{~m}$ above the river Seim level, some channels appeared : a bypass one, a water supplying one, a drainage one, etc. Building up the territory with the nuclear power station objects and asphalt pavements disrupted the natural water exchange between the atmosphere, the surface and the subsurface, so that influenced the surface and the groundwater runoff. The additional groundwater recharge sources were formed by injecting water from the cooling pond and partly from the canals, moisture condensation under the built-up and asphalted sections of the industrial site. In this connection, the depth and the camping deep-lying groundwater level have changed: near the cooling pond and canals it is $1,3 \div 2,2 \mathrm{~m}$, at the site $6,2 \div 9,0 \mathrm{~m}$ and on the territory that is not affected by the construction of $11,74 \div$ $19,60 \mathrm{~m}$. The direction of the groundwater flow is oriented from the cooling pond and canals to the west-northwest, south-south-east. The coefficient of the fertilizing of sands is $2,95 \mathrm{~m} /$ day sandy loam and loam $-0,0366$ $\div 0,6989 \mathrm{~m} /$ day. The split screen of the two streams are channels [2].

The cooling pond is fenced with a sand dam over $8600 \mathrm{~m}$ long. On the slope of the dam, facing the r. Seim (bypass channel), the areas 200 to $880 \mathrm{~m}$ have been allocated, on which there is leakage of water from the reservoir and the bottom thereof in the form of hollows and small streams, small gullies in the body of the dam and marsh vegetation at its base. The length of such areas, increased filtration of water, is about $30 \%$ of the total 


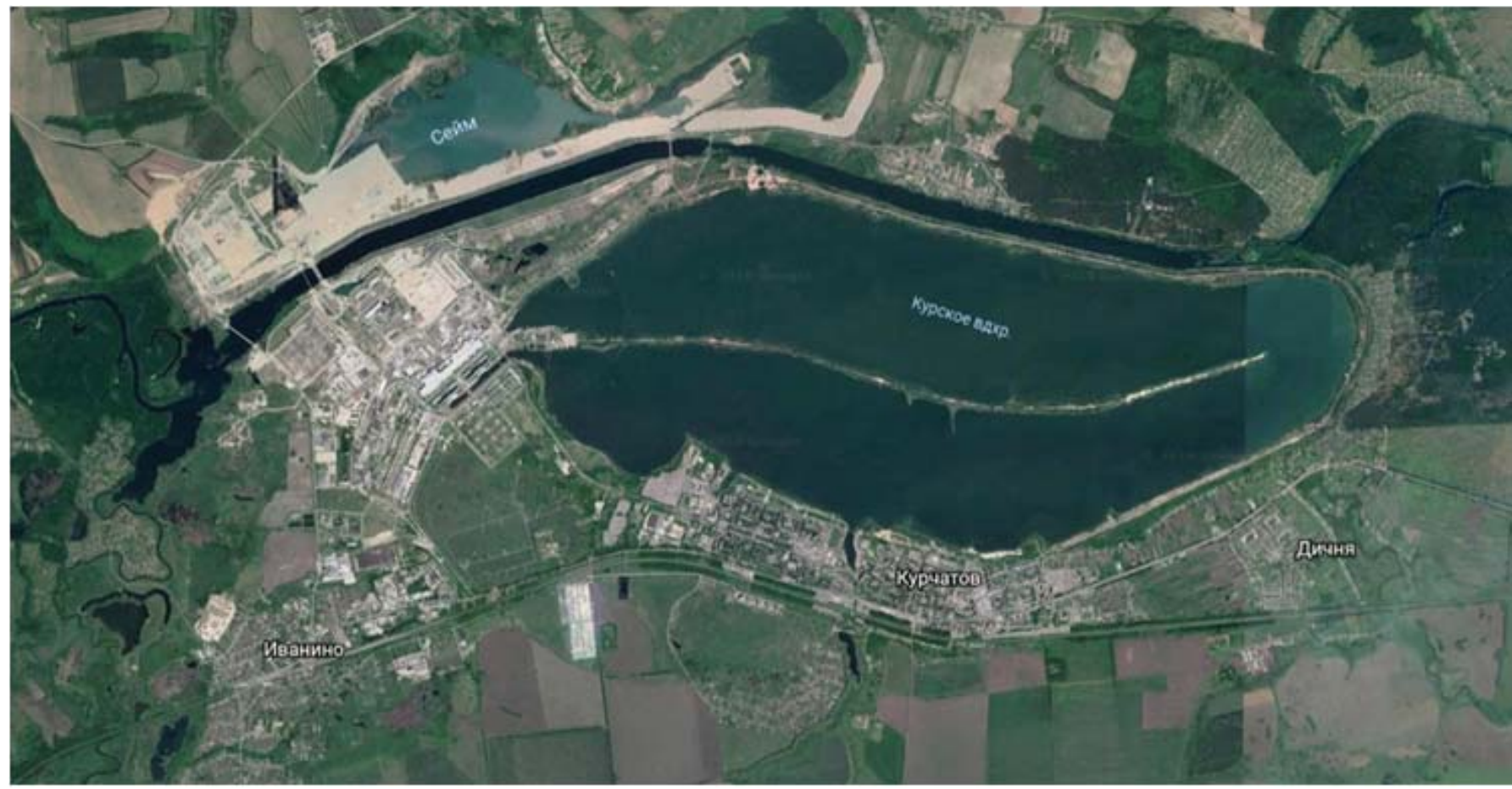

Figure 1: The location of the studied area

length of the dam. At such sites, there is a danger of the development of mechanical suffusion and subsequent subsidence of the dam body.

The filtration coefficient of the dam body is determined by the pumping method and is on average equal to $20-22 \mathrm{~m} /$ day. The water balance of the cooling pond is determined by the equation:

$$
Q_{1}+Q_{2}+Q_{3}=Q_{4}+Q_{5}
$$

The incoming part is as follows: the amount of precipitation falling on the area of the cooling pond on average is $0,36 \times 105 \mathrm{~m} 3 /$ day (Q1), the volume of water supplied by the pumping station is $2,16 \times 105 \mathrm{~m} 3 /$ day (Q2). The volume of groundwater (Q3) entering the cooler pond is not installed, but it is limited and probably insignificant, since the water mirror in the cooling pond is above the groundwater level. Thus, the incoming part of the cooling pond is equal to $2,52 \times 105 \mathrm{~m} 3 /$ day, and the consumption is: due to evaporation (Q4) - 0,984 × $105 \mathrm{~m} 3$ / day and filtration of water from the cooling pond -1 , $476 \times 105 \mathrm{~m} 3$ / day (Q5), a total of 2,45 × $105 \mathrm{m3} /$ day, which the smaller part of the cooling pond and requires maintaining a regime of continuous filling of the reservoir with water at a given level. To maintain the water level in the pond-cooler, water is constantly supplied from the $r$. Seim, volume 2,16 × $105 \mathrm{~m} 3$ / day, pump station, located on the enclosing dam.

\section{RESULTS AND DISCUSSIONS}

According to the peculiarities of changes in hydrogeological conditions depending on the technogenic and climat- ic factors within the territory of KNPS, three zones can be distinguished:

1. The coastal zone ( the table 1), near the reservoir (cooling pond) and canals, has the highest absolute elevations of standing of the groundwater level ( $152,22 \div 159,65 \mathrm{~m}$ ) and their close location from the surface $(1,3 \div 2,3 \mathrm{~m}$ and less), which causes flooding of areas adjacent to the pond-cooler (the village Uspenka, Dichnya, Leonovka, etc.) - houses, gardens and yards, in connection with what among other reasons continues the resettlement of the inhabitants of these settlements in Kurchatov. In the coastal zone, the main source of groundwater recharge is an invariant filtration of pond water and partly from channels. Groundwater recharge due to atmospheric precipitation has a subordinate significance; therefore, groundwater level fluctuations during the year are insignificant and depend mainly on changes in water levels in the cooling pond.

2. The area of building objects of the KNPS is the predominant part of the territory of waterproof coatings: asphalt sites and roads, buildings, structures and various utilities. Here the natural moisture exchange between a ground surface and the atmosphere is drastically disturbed: the infiltration of rain and melt waters has referred and reduced, so as evaporation and runoff. Since atmospheric precipitation almost does not affect fluctuations in groundwater levels, the latter are slowed down in time and has a constant amplitude. The absolute level of the groundwater water constitute $150,0 \div 151,4$ meters and their depth from the surface $-6,2 \div 9,0 \mathrm{~m}$. The raise of the groundwater level mainly occurs due to moisture condensa- 
Table 1: Characteristics of hydrogeological zones

\begin{tabular}{|l|c|c|c|}
\hline \multicolumn{1}{|c|}{ Name of the zone } & $\begin{array}{c}\text { Distance from the } \\
\text { cooling pond and } \\
\text { channels, } \mathrm{m}\end{array}$ & $\begin{array}{c}\text { Absolute marks of the } \\
\text { groundwater table, } \mathrm{m}\end{array}$ & $\begin{array}{c}\text { The depth of the } \\
\text { groundwater table to } \\
\text { the surface, } \mathrm{m}\end{array}$ \\
\hline $\begin{array}{l}\text { Coastal area of the in- } \\
\text { tensive filtration of water } \\
\text { from the cooling pond and } \\
\text { partly from the canals. }\end{array}$ & $40 \div 50$ to 125 & $152,22 \div 159,65$ & $1,30 \div 2,27$ \\
\hline $\begin{array}{l}\text { Building Area of the } \\
\text { NPP - influence of water } \\
\text { filtration from the cooling } \\
\text { pond and the canal }\end{array}$ & $\begin{array}{c}\text { from channels } \\
50 \div 110\end{array}$ & $150,0 \div 151,44$ & $6,20 \div 9,00$ \\
\hline $\begin{array}{l}\text { The outer zone is relative- } \\
\text { ly untouched by the influ- } \\
\text { ence of the construction to } \\
\text { the plant }\end{array}$ & $510 \div 980$ and more $150 \div 615$ & $148,82 \div 151,80$ & $10,0 \div 19,60$ \\
\hline
\end{tabular}

tion, water inflow from the neighboring stations and infiltration from the cooling pond and partly from channels. There exist the phenomenon of flooding of deep foundations structures to the plant due to a violation of the natural ground water regime and also the escapes from sanitation channels, and its capillary rise [3-5].

3. The outer zone, located at a distance of 0,5-1,0 km and more objects from water to the plant, yet characterized by undisturbed natural conditions (soil vegetation cover, ground water), where more pronounced fluctuations seasonal changes groundwater levels depending on the amount of precipitation, snowmelt and temperature conditions. The absolute elevations of groundwater levels vary from 148,82 to $151,80 \mathrm{~m}$, and the depth from 10 to $20 \mathrm{~m}$. Thus, the aquifer of the groundwater of the quaternary sediments in the area of the cooling pond KNPS receives additional power due to infiltration of water from the reservoir, which leads to an increase in its level in the coastal zone and contributes to flooding of the settlements of Leonovka, Uspenka and others located within of this zone, as well as the foundations of the objects to the KNPS of the deep foundation in the zone of the industrial site. In this regard, at present, in the survey and design of various types of civil and industrial construction, the determination of extreme values of groundwater levels, the timing of their occurrence, the duration of standing, etc. is of great importance [3,6-8]. It is not by chance that in SNiP 2.02-01.83 "Foundations of buildings and structures" there is a strict requirement that it is mandatory to determine the highest levels of groundwater for the estimated period of operation of buildings and structures, which, depending on their wear, has a duration of 15 or 25 years. The presence of a forecast of changes in hydrogeodynamic and hydrogeological conditions is justified in MDS 115.99 "Guidelines for the examination of engineering survey materials for the feasibility study (projects, work projects) construction of facilities."

\section{CONCLUSION}

Ensuring the protection of the population from of the consequences of flooding is the most acute moment, given the current state of the Housing and Communal Services Kursk and Kursk region. Social security can be achieved by introducing real estate insurance programs and property, preferential loans for the restoration of damaged housing and et al. The turning point in the problem of flooding of residential areas, the conviction of the authors, would serve as the following:

1. Transaction of the problem of flooding to the economic field: the introduction of legal status to the order of valuation of the degree of flooding of territories (a reduction factor to monetary value of land) and actual losses from flooding; the introduction of loss recovery mechanisms; the creation of levers of encouragement to investment activity on flooded areas and etc.

2. Organization of monitoring the state of groundwater (in features on built-up areas) and the creation of large-scale maps of risks of flooding (to ensure a monetary assessment of land plots and possible losses).

3. The widespread introduction of geophysical research (in including and distance) for groundwater level mapping, their pollution and further monitoring of natural and man-made waters and forecasting risks of flooding.

4. The development of permanent geofiltration model study area, including the surrounding area of the 
possible impact of the planned construction for the purpose of forecasting of hydro-geological conditions at all stages of building design and construction of individual buildings and structures.

The prediction of the natural dynamics of the state of the environment is often a laborious task. Direct observations required to evaluate this dynamic may require considerable resources and time, sometimes disproportionately large compared to other costs. Therefore, in practice, it is often necessary to find a compromise between limiting the amount of research and reducing the accuracy of forecasts with insufficient observation series.

There are many similar examples of the negative impact on the groundwater within the territory under consideration. At the same time, the very modest water supply of the region, the problems of water supply of settlements and the tense general ecological situation requires very careful treatment to groundwater in particular, and to nature in general from both the economic entities and the population.

\section{REFERENCES}

1. Lushnikov EA, Khaustov VV, Dubyaga AP. On some environmental problems of the Kursk region KMA // Optimization of natural resources and protection of the environment appropriate medium: with b. report scientific conf. - Orenburg, OGU, 1998. pp. 121-122.

2. Lushnikov EA, Khaustov VV, Dubyaga AP. About the phenomena of flooding in the Kursk region of the KMA // Hydrogeological about Gia and Karst: a b. tons of ores scientific conf. - Perm, PGU, 1999. pp. 76-83.
3. Khaustov VV. On the impact on groundwater within one of the industrial-residential agglomerations of the city of Kursk // News of South-West State University, 2013, No. 5 (50). - pp. 236-242.

4. Khaustov VV, Kostenko VD, Dubyaga AP. To the problem of environmental audit of real estate objects // Proceedings of the South-West State University, ser. Technics and techology. 2012, №2, part 3. - pp. 258-262.

5. Khaustov VV, Kostenko VD, Dubyaga AP. The influence of some technogenic processes in the hydrolithosphere on the operational reliability of real estate in the Kursk region of the KMA // News of the South -Western State University , 2011, No. 5 (38). - pp. 63-72.

6. Novikova, T., Khaustov, V., \& Guseinov, T. [2018]. Cadastral valuation based upon the environmental factors using the City of Kursk as an example. Journal of Applied Engineering Science, 16(1), 104-106.

7. Pokrovsky VI. The research underflooding processes of architecture monuments on the territory of Tomsk with using GIS-technology // 14th SGEM GeoConference on Science and Technologies In Geology, Exploration and Mining, www.sgem.org, SGEM2014 GeoConference Proceedings, Vol. (2)2014. - pp. 935 - 942.

8. Nikanorov AM, Bartsev OB, Gar'kusha DN, Zubkov EA, Minina LI. Dynamics, Cxtent, and Causes of Underflooding of Populated Localities in the Southern Rostov Oblast // Water Resources, (44)2017, Issue 7. - pp. 952-962. 